\title{
Antioxidant Activity Test of Acetone and Ethanol Extracts of Cocoa (Theobroma cacao L.) Beans Husk
}

\author{
*Siti S. K. Pandjo, Kasmudin Mustapa \& Purnama Ningsih
}

Pendidikan Kimia/FKIP - Universitas Tadulako, Palu - Indonesia 94119

Received 3 December 2020, Revised 7 January 2021, Accepted 1 February 2021

doi: $10.22487 /$ j24775185.2021.v10.i1.pp1-8

\begin{abstract}
Cocoa beans husk is waste produced from the cocoa processing industry containing alkaloid, flavonoid, tannin, saponin, and triterpenoid compounds. This material has the potential to be used as a source of natural antioxidant compounds. This study aimed to determine the antioxidant activity of cacao beans husk extracts by comparing acetone and ethanol as solvents through the extraction process. This antioxidant activity was determined using the DPPH (1,1-diphenyl-2-picrylhydrazyl) test method measured by UV-Vis spectrophotometer after adding an extract of cocoa beans husk. The positive control was vitamin $C$, while the negative control was DPPH solution dissolved in ethanol. The results showed that the extract of cacao beans husk has more potent antioxidant activity with a lower IC $C_{50}$ value of $181.2 \mathrm{ppm}$, while the acetone extract has an IC $C_{50}$ value of $247.9 \mathrm{ppm}$
\end{abstract}

Keywords: Antioxidant, cocoa beans husk, DPPH, ethanol, acetone

\section{Introduction}

Cocoa (Theobroma cacao L.) is a plantation crop that produces cocoa beans and is one of the financial sources of farmers and the state. Indonesia's cocoa plantations are approximately 1.72 million ha, with an average cocoa bean production of about 776.880 tons. Sulawesi Tengah ranks first as a cocoa-producing region in Indonesia with a contribution of 156.63 thousand tons (21.69\%) (Pusat Data dan Sistem Informasi Pertanian, 2016).

Sulawesi Tengah high cocoa productivity encourages the government to build a chocolate processing industry. This chocolate processing industry processes fermented cocoa beans from farmers into semi-finished chocolate products, which are then sold and distributed to small and medium industries (SMEs) in Sulawesi Tengah. Every industrial processing must produce waste in the process, as does this chocolate industry. The processing process produces waste in the form of cocoa bean skin that is still underutilized. Cocoa bean skin is likely to be used as a source of antioxidants because it contains polyphenol compounds with a total phenolic of $5.78 \%$ (Lecumberri et al., 2007). According to Kayaputri et al. (2014), cocoa bean skin contains alkaloids, flavonoids, tannins, saponins, and triterpenoids, so that the skin cocoa beans have the opportunity to be used as a source of antioxidants.

Antioxidant compounds are needed by the body to protect against free radical attacks (Sayuti
\& Yenrina, 2015). Antioxidants are divided into two groups, namely synthetic and natural. Synthetic antioxidants are obtained from chemical synthesis, while natural antioxidants come from the extraction of natural ingredients that have the potential to capture free radicals (Isfahlan et al., 2010). Free radicals are an atom or molecule that has unpaired electrons. These paired electrons cause highly reactive free radicals that will then capture or take electrons from other compounds such as proteins, lipids, carbohydrates, and DNA to neutralize themselves. Free radicals can enter the body and attack healthy cells causing them to lose their function and structure. The adverse effects of free radicals on the body can be prevented by antioxidant compounds (Sadeli, 2016).

Antioxidant compounds from the skin cocoa beans can be obtained by extraction, one of which is by the maceration method. Maceration was extraction using active compounds based on the level of pattern, each solvent's ability to attract or bind to secondary metabolites contained in the sample. The polar solvents will attract or bind to active compounds that are polar and non-polar solvents will attract non-polar active compounds, or also called like dissolves like (Khopkar, 2010).

Phenolic compounds have different affinity for solvent polarity properties Therefore, extracting compounds in natural material tissues should be used solvents of varying levels of polarity. The degree of polarity will determine the extraction yield and antioxidant activity contained in the extract (Taroreh et al., 2015). In general, water, ethanol,

*Correspondence:

Siti S. K. Pandjo

e-mail: sitisuhertina@gmail.com

(c) 2021 the Author(s) retain the copyright of this article. This article is published under the terms of the Creative Commons Attribution License 4.0, which permits unrestricted non-commercial use, distribution, and reproduction in any medium, provided the original work is properly cited. 
methanol, acetone and ethyl acetate are solvents used to extract natural materials.

Research related to the antioxidant activity of cocoa bean skin so far conducted with acetone solvents conducted by Utami et al. (2017) while for other solvents are still lacking, so that exploration of solvent types is needed in order to obtain better solvents to extract antioxidants in the cocoa beans skin. Testing of antioxidant activity is most common using the DPPH test (1,1-diphenyl-2pycrilhydrazyl). The working principle of this test is the measurement of antioxidant activity based on a measured decrease in DPPH absorption at a wavelength of $517 \mathrm{~nm}$ as a result of the presence of an antioxidant compound (Pisoschi et al., 2009).

This paper presents testing of antioxidant activity in cocoa bean skin waste by comparing two types of solvents, namely acetone and ethanol, in producing extracts that have more potent antioxidant activity through the extraction process of cocoa bean skin.

\section{Method}

The tools used in this study are blenders, analytical balance sheet, measuring flask, Erlenmeyer flask, beath glass, measuring glass, test tube, test tube rack, stir bar, spatula, funnel, drip pipette, filter paper, aluminum foil, shaker, Buchner vacuum funnel, silica gel KLT plate $60 \mathrm{~F} 254$, chamber, capillary pipe, rotary vacuum evaporator, and UV-Vis spectrophotometer. The ingredients used are cocoa bean skin, n-hexane (Merck), ethanol 90\%, 90\% acetone, Dragendorff reagents, $\mathrm{Mg}$ metals, $\mathrm{HCl} 2 \mathrm{~N}$, concentrated $\mathrm{HCl}$ (Merck), concentrated $\mathrm{H}_{2} \mathrm{SO}_{4}$ (Merck), chloroform (Merck), anhydrous acetate $(M e r c k), \mathrm{FeCl}_{3}, \mathrm{AlCl}_{3}$, distilled water, vitamin C, and 2,2-diphenyl-1-picrilhydrazil (DPPH).

\section{Cocoa Bean Ari Skin Extraction}

150 grams of cocoa bean skin powder extracted using $\mathrm{n}$-hexane solvents as much as 225 $\mathrm{mL}$ in maceration for two days. Stirring is carried out for 1 hour at the time of immersion. On the second day, separated between residue and filtrate. The residue that has been separated was left for four days (Yumas, 2017).

20 grams of cocoa bean skin powder that has been fat-free is then moderated for $3 \times 24$ hours, each with $90 \%$ ethanol solvent and $90 \%$ acetone as much as $200 \mathrm{~mL}$. After that, it is separated between the residue and the filtrate. The filtrate obtained first tested qualitatively using KLT then accommodated while the residue is pre-moderated until the solvent no longer shows discoloration (Departemen Kesehatan RI, 2000). The last filtrate that no longer shows the difference in color before being combined with other filtrates is rechecked to analyzed that the filtrate no longer contains antioxidant compounds that are expected by KLT in the following way:

\section{Alkaloids}

Filtrate attached to the KLT plate was then diluted with the eluent BAW (Butanol-Acetic acidWater) 4:1:5 then sprayed using a Dragendorf stain remover. The positive results will show orangebrown color (Wagner et al., 1984).

\section{Flavonoids}

Filtrate attached to the KLT plate was then diluted with the eluent BAW (Butanol-Acetic acidWater) 4:1:5 then sprayed using $\mathrm{AlCl}_{3}$ stain remover. Positive results will show yellow color in UV rays with wavelengths of $366 \mathrm{~nm}$ (Wagner et al., 1984)

\section{Tannins}

The filtrate was attached to the KLT plate and then diluted with the eluent BAW (ButanolAcetic acid-Water) 4:1:5 then sprayed using $\mathrm{FeCl}_{3}$ stain remover $10 \%$. The positive results will show a green-blackish color (Wagner et al., 1984).

After checking the filtrate maceration results are combined, evaporated solvents using rotary vacuum evaporator on ethanol solvents used temperature $45{ }^{\circ} \mathrm{C}$ while solvent acetone used temperature $30{ }^{\circ} \mathrm{C}$, so obtained concentrated extract of cocoa bean skin from ethanol solvents and acetone solvents.

\section{Qualitative Test Extract}

Each of the concentrated extracts before the antioxidant activity test is carried out a qualitative test to see the content of chemical compounds contained in the extract.

\section{Alkaloid Test}

0.5 grams of the extract is dissolved in $5 \mathrm{~mL}$ $\mathrm{HCl} 2 \mathrm{~N}$, then filtered. Filtrate is taken $1 \mathrm{~mL}$ then added 2 drops dragendorff reagents. A positive result with the formation of red deposits (Tiwari et al., 2011).

\section{Flavonoid Test}

0.5 grams of extract was dissolved in $5 \mathrm{~mL}$ ethanol. Then added 0.1 grams of magnesium metal and ten drops of concentrated $\mathrm{HCl}$, when formed orange-red to purple-red indicates flavonoids or orange-yellow indicates the presence of flavons, kalkon, and auron (Fajriah \& Megawati, 2015).

\section{Tannin Test}

0.5 grams of extract dissolved in $5 \mathrm{~mL}$ ethanol, then added three drops of $\mathrm{FeCl}_{3} 1 \%$. If a bluish-black or green color is formed, then the sample positively contains tannins (Minarno, 2015).

\section{Saponin Test}

0.5 grams of the extract was put in a test tube and added $10 \mathrm{~mL}$ of hot water, cooled, and shaken firmly for 10 seconds. If the foam was formed as high as 1 to $10 \mathrm{~cm}$ for not less than 10 minutes and at the addition of 1 drop of $\mathrm{HCl} 2 \mathrm{~N}$, the froth did not disappear, then the positive sample contains saponins (Fajriah \& Megawati, 2015). 


\section{Triterpenoid and Steroid Tests}

0.5 gram of the extract was put into the test tube, then added $2 \mathrm{~mL}$ chloroform and ten drops of anhydrous acetate, and three drops of concentrated $\mathrm{H}_{2} \mathrm{SO}_{4}$. A positive reaction is indicated by the formation of a red or purple-red solution for the indication of triterpenoids then a green-blue solution color for steroid indications (Harborne, 1987).

\section{Antioxidant Activity Test with DPPH Test}

\section{Making Solution DPPH 50 ppm}

$5 \mathrm{mg}$ of DPPH was dissolved with ethanol in a $100 \mathrm{~mL}$ measuring flask, then sufficient in volume with ethanol to the boundary mark line.

\section{Making Blanko Solution}

A $50 \mathrm{ppm}$ DPPH solution of $2 \mathrm{~mL}$ pickpocket was put into the test tube then added ethanol $2 \mathrm{~mL}$ and covered with aluminum foil then homogenized and silenced for 30 minutes.

\section{Making a Test Solution for Cocoa Bean Ari Skin Extract}

$12.5 \mathrm{mg}$ of each cocoa bean skin extract put into two $25 \mathrm{~mL}$ measuring flask. The first measuring gourd is added with ethanol to the limit mark, and the second measuring flask is added with acetone to the limit mark so that a master solution with a concentration of $500 \mathrm{ppm}$ is obtained. Furthermore, each master solution is made of series concentrations of $20,40,60$, and $80 \mathrm{ppm}$, respectively.

\section{Making Vitamin C Comparing Solution}

$12.5 \mathrm{mg}$ of vitamin $\mathrm{C}$ was added with a little aquades and then sufficient volume up to 25 $\mathrm{mL}$ so that the main solution of vitamin $\mathrm{C}$ with a concentration of $500 \mathrm{ppm}$ is obtained. Furthermore, each solution was made of series concentrations of $20,40,60$, and $80 \mathrm{ppm}$, respectively.

\section{Absorption Measurement using UV-Vis Spectrophotometer}

\section{Measurement of Blanko Solution Absorption}

The blank solution is inserted into the cuvette and then measured absorption at a wavelength of $517 \mathrm{~nm}$.

\section{Test Solution Absorption Measurement}

Each $2 \mathrm{~mL}$ of test solution inserted into the test tube was added with $2 \mathrm{~mL}$ of DPPH solution, homogenized, then silenced for 30 minutes, and put into the next cuvette measured absorption at a wavelength of $517 \mathrm{~nm}$.

\section{Measurement of Vitamin C Comparison Solution Absorption}

Each $2 \mathrm{~mL}$ of comparative solution is inserted into the test tube added with $2 \mathrm{~mL}$ of DPPH solution, homogenized, then silenced for 30 minutes, and put into the cuvet then measured its absorption at a wavelength of $517 \mathrm{~nm}$.
The parameter commonly used to interpret the results of THE DPPH test was the efficient concentration $\left(\mathrm{EC}_{50}\right)$ or often called $\mathrm{IC}_{50}$, which is the concentration that causes the loss of $50 \%$ of DPPH activity (Molyneux, 2004). The $\mathrm{IC}_{50}$ value was calculated using the percent inhibition of the test was performed. Percent inhibition can be calculated using the formula:

$$
\% \text { inhibition }=\frac{\text { sample blan } \square \quad \text { absorption }}{\text { blank absorption }} \times 100
$$

The sample concentration and percent of inhibition obtained were plotted respectively on the $\mathrm{x}$ and $\mathrm{y}$ axes on linear regression equations. The equation is used to determine the $\mathrm{IC}_{50}$ value of each sample stated with a value of $y$ of 50 and $x$ value to be obtained as $\mathrm{IC}_{50}$. The $\mathrm{IC}_{50}$ value represents the concentration of sample solution needed to reduce DPPH free radicals by $50 \%$ (Nurjanah et al., 2011).

IC $_{50}$ value of $<50 \mathrm{ppm}$ indicates very active antioxidant power, $\mathrm{IC}_{50}$ value of $50-100 \mathrm{ppm}$ indicates active antioxidant power, $\mathrm{IC}_{50}$ value of 101-250 ppm indicates moderate antioxidant strength, IC 50 value of $250-500 \mathrm{ppm}$ indicates weak antioxidant strength, and $\mathrm{IC}_{50}$ value $>500 \mathrm{ppm}$ indicates inactive antioxidant power (Jun et al., 2003).

\section{Results and Discussion}

\section{Cocoa Bean Ari Skin Extraction}

The extraction of cocoa bean skin is done through two stages of extraction. The first stage is extracted using $\mathrm{n}$-hexane solvents to produce skin powder fat-free cocoa beans. At this extraction, the phase obtained $95.61 \mathrm{~g}$ of fat-free powder cocoa bean skin and concentrated extracts of cocoa bean skin using solvent acetone and ethanol as much as 10.25 and $10.01 \mathrm{~g}$, respectively.

The extraction process is carried out in a cold way that is maceration. This method is based on immersion of the sample inside the solvent so that the solvent will penetrate the cell wall and into the cell cavity containing the active compound. The active compound will dissolve in the appropriate solvent due to the difference in concentration between the active substance in the cell and outside the cell so that the adjacent solution is jostling and pushed out. The event lasts continuously until there is a concentration equilibrium between the solution outside and the one in the cell (Voight, 1995). Maceration is chosen because of its easy workmanship, simple use of tools and can minimize the influence of temperature in the extraction process.

Before the third filtrate maceration process is stopped, checking using KLT, to ensure that the filtrate no longer contains the desired antioxidant compounds as a sign that the solution equilibrium has been achieved so that the maceration repeating process can be stopped; in this check, all compounds look negative on the extract of acetone skin cocoa beans, while in ethanol extract of cocoa bean skin 
there are still positive results for alkaloid compounds. This means that the extraction with ethanol solvents has not reached equilibrium for alkaloid compounds so that the remuneration process can still be done again if you want to optimize the extracted compounds.

\section{Qualitative Test Extract}

Qualitative tests were conducted on concentrated extracts of cocoa bean skin for alkaloid compounds, flavonoids, tannins, saponins, triterpenes, and steroids

\section{Identification of Alkaloids}

Alkaloid testing used dragendorff reagents. The positive test result using this reagent is the obtaining of dark brown to yellow deposits. In the manufacture of Dragendorff reagents, bismuth nitrate is dissolved with acid so that there is no hydrolysis reaction because bismuth salts are easily hydrolyzed to form bismutil ions $\left(\mathrm{BiO}^{+}\right)$. The addition of this acid serves to keep $\mathrm{Bi}^{3+}$ ions in the solution so that the equilibrium shifts to the left. $\mathrm{Bi} 3+$ ions then react with potassium iodide forming black deposits of bismuth(III) iodide, which then in excess potassium iodide form potassium tetraiodobismutat (Svehla, 1990).

Alkaloids contain nitrogen that has a pair of free electrons so that it can be used to form coordinate covalent bonds with metal ions. In alkaloid tests with Dragendorff recalculation, it is estimated that nitrogen is used to form covalent coordinate bonds with $\mathrm{K}^{+}$, which are metal ions forming sediment; this deposit is potassium-alkaloid (Marliana et al., 2005). The results showed that both extracts of cocoa bean skin positively contain alkaloids, but in ethanol extract, there are deposits while acetone extract only occurs a change in the color of the solution to red not until sediment is formed.

\section{Identification of Flavonoids}

This flavonoid test using the Wilstater test shows orange or red-yellow, which means the positive presence of flavonoids. Magnesium and $\mathrm{HCl}$ in the Wilstater test formed $\mathrm{H}_{2}$ gas bubbles, while $\mathrm{Mg}$ metal with concentrated $\mathrm{HCl}$ in this test served to reduce benzopyran core contained in flavonoid structure so that discoloration becomes red or orange (Marliana et al., 2005). A plant extract containing flavonoids will form flavilium salts when the addition of $\mathrm{Mg}$ and $\mathrm{HCl}$ are red or orange (Achmad, 1986). Both cocoa bean skin extracts, namely ethanol extract and acetone extract, showed positive results that are orange for ethanol extract and red color for acetone extract.

\section{Tanin Identification}

Tannin testing using iron(III) chloride reaction. The result of this positive reaction test is the formation of blackish-green or blackish blue. The addition of $\mathrm{FeCl}_{3} 1 \%$ in a positive extract containing tannins will show a blackish-green or blackish blue color due to the reaction that occurs between tannins and $\mathrm{Fe}^{3+}$ ions forming complex compounds that indicate such discoloration (Harborne, 1987). Both cocoa bean skin extracts, namely ethanol extract and acetone extract showed positive results that are blackish green for ethanol extract and blackish blue color for acetone extract.

\section{Saponin Identification}

This saponin test using the forth test with positive results is shown by the presence of stable foam not less than 10 minutes and after the addition of $\mathrm{HCl} 2 \mathrm{~N}$. The onset of the foam indicates the presence of glycosides that have the ability to form foam in hydrolyzed water into glucose and other compounds (Rusdi, 1990). Both cocoa bean skin extracts, namely ethanol extract and acetone extract, showed negative results.

\section{Identification of Triterpene and Steroids}

Triterpene and steroid testing using Lieberman-Burchard test is a mixture of acetate anhydride and concentrated $\mathrm{H}_{2} \mathrm{SO}_{4}$ that gives a green-blue color. Positive results were shown by the formation of a red or purple-red solution for triterpenoid indications and then green-blue solution color for steroid indications (Harborne, 1987). The results showed that both cocoa bean skin extracts were negative for steroid compound content because there was no visible discoloration of the solution to green-blue; however, acetone extract showed positive results for triterpene compounds due to the formation of purple-red solution in the solution while in ethanol extract showed negative results.

After a qualitative test on cocoa bean skin extract, it was seen that extracts from acetone solvents have positive results in 4 types of compounds: alkaloids, flavonoids, tannins, and triterpenes. While extracts from ethanol solvents only have positive results in 3 types of compounds, namely alkaloids, flavonoids, tannins. These compounds can be extracted according to the same level of pattern as the solvent. According to Saifudin (2014), most terpenoid compounds have non-polar properties so that they can dissolve in non-polar and semi-polar solvents; therefore, triterpene compounds can be extracted in acetone solvents that have semipolar properties. However, other secondary metabolite compounds mostly have semipolar and polar properties whose solubility depends on the number of carbon chains and hydroxyl groups of each type.

\section{Antioxidant Activity Test with DPPH Test}

The implementation of the antioxidant activity test of cocoa bean extract is carried out using DPPH test method. This method was chosen because it is simple, easy, fast, and sensitive and requires very few samples (Molyneux, 2004). This method of testing is based on the ability of these antioxidant compounds to dampen free radicals. Free radicals used are DPPH (1,1-diphenyl2picrylhydrazyl). 
$\mathrm{DPPH}$ is a stable free radical due to the localization of electrons throughout the molecule. The localization of free electrons in these molecules causes the onset of the thick purple color of DPPH. If the solution of DPPH is mixed with a substance that can contribute hydrogen atoms, then the resulting reduced form of DPPH is accompanied by reduced intensity of purple color solution (Pisoschi et al., 2009).

Observations on color intensity in this study were conducted on cocoa bean skin extract in the form of solutions made in several concentration variations, namely 20, 40, 60, and $80 \mathrm{ppm}$ with duplo repetition. The solution is then reacted with a solution of DPPH (1,1-diphenyl2picrylhydrazyl) and incubated for 30 minutes in dark conditions at room temperature. The incubated solution is then measured using a UV-Vis spectrophotometer at a wavelength of $517 \mathrm{~nm}$ (Molyneux, 2004).

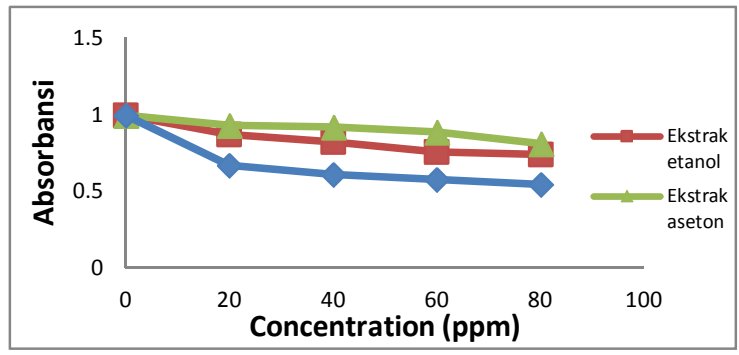

Figure 1. Relationship between absorption and concentration

The measurement of absorbance from cocoa bean extract and vitamin $\mathrm{C}$ can be seen in Figure 1. The results showed that the absorption value of DPPH is decreasing as the concentration of cocoa bean extract increases. The same is also indicated by vitamin $\mathrm{C}$.

This decrease in absorption occurs due to the reduction reaction in $\mathrm{DPPH}$ by antioxidant compounds; according to the principle of this method, DPPH is reduced by the process of hydrogen or electron donation so that the color changes from purple to bright yellow comparable to the amount of electron donation (Dris \& Jain, 2004). The change in color intensity is related to the number of DPPH electrons that capture hydrogen atoms from antioxidant compounds (Molyneux, 2004). The reaction between DPPH and antioxidant compounds can be seen in Figure 2.

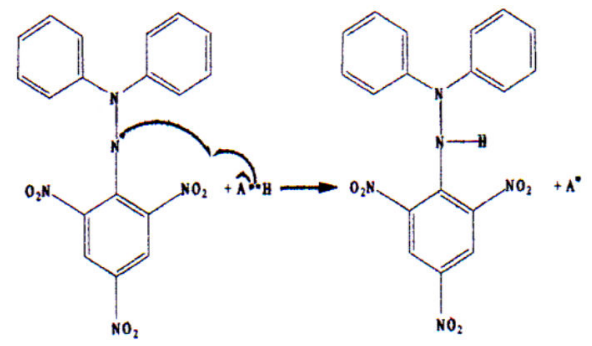

Figure 2. Reactions between DPPH free radicals and antioxidant compounds (Windono, 2001)

The reduced intensity of purple color, along with the increasing concentration value of cocoa bean skin extract, indicates an increased antioxidant ability to capture DPPH free radicals (Molyneux, 2004). The results of absorbance measurements are then used to determine the percentage of free radical inhibition by skin extracts cocoa beans and vitamin $\mathrm{C}$ at various concentrations.

A comparison of the percentage value of free radical inhibition by cocoa bean extract and vitamin $\mathrm{C}$ can be seen in Figure 3. Based on Figure 3 , we can see that the percent of vitamin C inhibition is greater than that of both cocoa bean skin extracts and then followed by cocoa bean skin extract with ethanol solvents that are greater than the skin extract cocoa beans with acetone solvents. The difference of percent inhibition between cocoa bean extract and vitamin $C$ looks quite significant; this can happen to look at the qualitative test results of cocoa bean skin extract, which still shows negative results in some types of antioxidant compounds tested. This certainly affects the bland power of the cocoa bean extract itself. In addition, it is also caused by vitamin $\mathrm{C}$ is a pure compound, while the extract of cocoa bean skin is a mixed compound, where the possibility of the presence of compounds that are not antioxidants that can affect the blandness of the skin extract cocoa beans. 


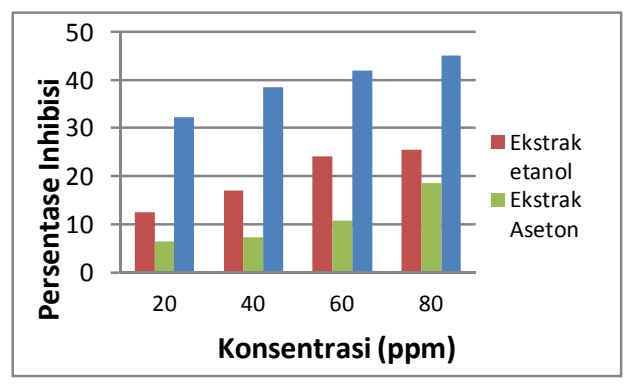

Figure 3. Profile comparison percentage of inhibition extracts and vitamin $\mathrm{C}$

The parameter commonly used to interpret the results of DPPH test is the efficient concentration $\left(\mathrm{EC}_{50}\right)$ or often called $\mathrm{EC}_{50}$, which is the concentration that causes the loss of $50 \%$ of $\mathrm{DPPH}$ activity. The smaller the EC 50 value indicates, the greater the antioxidant activity (Molyneux, 2004). The $\mathrm{EC}_{50}$ value is obtained by graphing between the percent value of inhibition and the concentration value obtained from the
DPPH free radical inhibitor test. The percent value of inhibition is entered on the $\mathrm{X}$ axis and the concentration value is entered on the $\mathrm{Y}$ axis in one whole relationship graph (Nurjanah et al., 2011). Graph of the relationship between percent inhibition and concentration of cocoa bean extract can be seen in Figures 4 and 5 while for vitamin C in Figure 6.

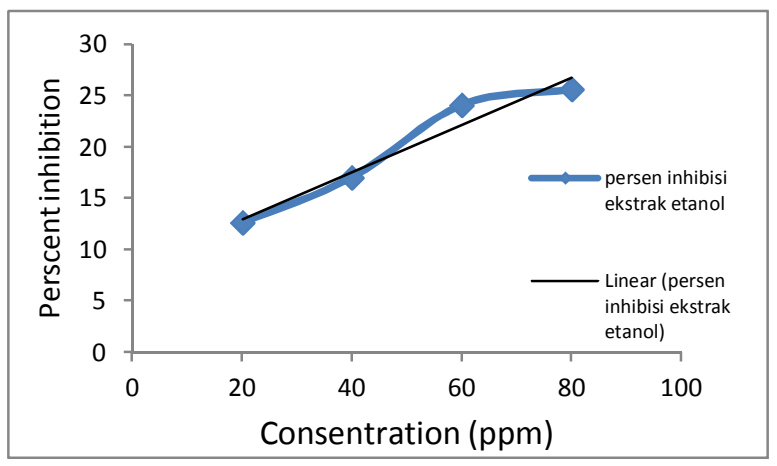

Figure 4. Relationship between percent inhibition and concentration of ethanol extract of cocoa bean skin

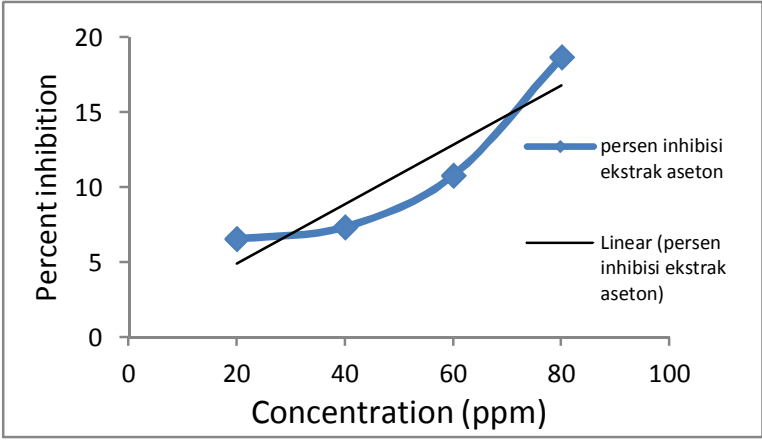

Figure 5. Relationship between percent inhibition and concentration of acetone extract of cocoa bean skin

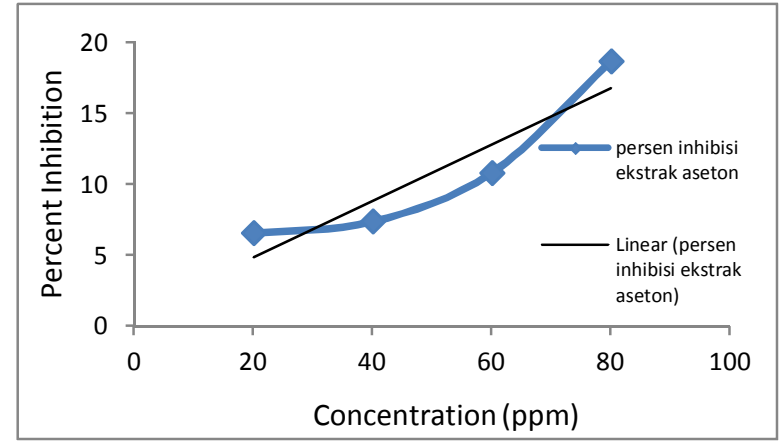

Figure 6. Relationship between percent inhibition and vitamin $\mathrm{C}$ concentration 
$\mathrm{IC}_{50}$ value obtained from ethanol extract calculations, acetone extract of cocoa beans, and vitamin C, respectively, are $181.2 \mathrm{ppm}, 247.939$ $\mathrm{ppm}$, and $100.191 \mathrm{ppm}$. $\mathrm{IC}_{50}<50 \mathrm{ppm}$ values show highly active antioxidant power, $\mathrm{IC}_{50}$ values of 50$100 \mathrm{ppm}$ show active antioxidant strength, $\mathrm{IC}_{50}$ values of 101-250 ppm show moderate antioxidant strength, $\mathrm{IC}_{50}$ values of $250-500 \mathrm{ppm}$ show weak antioxidant strength, and $\mathrm{IC}_{50}>500 \mathrm{ppm}$ values show inactive antioxidant power (Jun et al., 2003). Vitamin C, as a comparison, has $\mathrm{IC}_{50}$ values ranging from $50-100 \mathrm{ppm}$, which are categorized as powerful antioxidants. Meanwhile, cocoa bean skin can be categorized as a natural antioxidant that has moderate activity because the $\mathrm{IC}_{50}$ value ranges from $101-250$ ppm. However, when both cocoa bean skin extracts are compared then, cocoa bean skin extract with ethanol solvents has more potent antioxidant activity than cocoa bean skin extract with acetone solvent because the smaller the $\mathrm{IC}_{50}$ value indicates, the more potent its antioxidant activity (Molyneux, 2004)

\section{Conclusions}

Cocoa bean skin extract using ethanol solvents has more potent antioxidant activity with $\mathrm{IC}_{50}$ value of $181.2 \mathrm{ppm}$ while $247.939 \mathrm{ppm}$ for acetone extract of cocoa bean skin. Both fall into the category of moderate antioxidant activity.

\section{Acknowledgments}

The author's gratitude was given to the Head of Palu Chocolate House UPT and the laboratory of Chemistry Education Faculty of Teacher Training and Education of Tadulako University, who helped the author in completing this research

\section{References}

Achmad, S. A. (1986). Kimia organik bahan alam. Jakarta: Karnunika.

Dris, R., \& Jain, S. M. (2004). Production practices and quality assessment of food crops: Quality handling and evaluation. New York: Kluwer Academic Publisher.

Fajriah, S., \& Megawati. (2015). Penapisan fitokimia dan uji toksisitas dari daun myristica fatua HOUTT. Chimica at Natura Acta, 3(3), 116-119.

Harborne, J. B. (1987). Metode fitokimia (Edisi kedua). Bandung: ITB.

Isfahlan, A. J., Mahmoodzadeh, A., Hassanzadeh, A., Heidari, R., \& Jamei, R. (2010). Antioxidant and antiradical activities of phenolic extracts from Iranian almond (Prunus amygdalus L.) hulls and shells. Scientific and Technological Research Council of Turkey, 34(2), 165-173.

Jun, M., Fu, H. Y., Hong, J., Wan, X., Yang, C. S., \& Ho, C. T. (2003). Comparison of antioxidant activities of isoflavonoids from kudzu root (Puereria labata ohwl). Journal of Food Science, 68(6), 2117-2122.

Kayaputri, I. L., Sumanti, D. M., Djali, M., Indiarto, R., \& Dewi, D. L. (2014). Kajian fitokimia ekstrak kulit biji kakao (Theobroma cacao L.). Chimica at Natura Acta, 2(1), 83-90.

Khopkar, S. M. (2010). Konsep dasar kimia analitik. Jakarta: UI Press.

Lecumberri, E., Mateos, R., Pulido, Maria, I., Ruperez, P., Goya, L., \& Bravo, L. (2007). Dietary fibre composition, antioxidant capacity and physico-chemical properties of a fibre-rich product from cocoa (Theobroma cacao L.). Food Chemistry, 104(3), 948-954.

Marliana, S. D., Suryanti, V., \& Suyono. (2005). Skrining fitokimia dan analisis kromatografi lapis tipis komponen buah labu siam (sechium edule jacq. swartz.) dalam ekstrak etanol. Biofarmasi, 3(1), 26-31.

Minarno, E. B. (2015). Skrining fitokimia dan kandungan total flavonoid pada buah carica pubescens Lenne dan K. Koch di kawasan Bromo, Cangar, dan Dataran Tinggi Dieng. ElHayah: Jurnal Biologi, 5(2), 73-82.

Molyneux, P. (2004). The use of the stable free radical diphenylpicrylhydrazyl (DPPH) for estimating antioxidant activity. Journal Science and Technology, 26(2), 211-219.

Nurjanah, Izzati, L., \& Abdullah, A. (2011). Aktivitas antioksidan dan komponen bioaktif kerang pisau (Solen spp). Indonesian Journal of Marine Sciences, 16(3), 119-124.

Pisoschi, A. M., Cheregi, M. C., \& Danet, A. F. (2009). Total antioxidant capacity of some commercial fruit juices. Molecules, 14(1), 480493.

Departemen Kesehatan RI. (2000). Parameter standar umum ekstrak tumbuhan obat. Jakarta: Departemen Kesehatan Republik Indonesia.

Pusat Data dan Sistem Informasi Pertanian. (2016). Out look kakao: Komoditas pertanian subsektor perkebunan. Jakarta: Pusat Data dan Sistem Informasi Pertanian Kementerian Pertanian.

Rusdi. (1990). Tetumbuhan sebagai sumber bahan obat. Padang: Pusat Penelitian Universitas Andalas.

Sadeli, R. A. (2016). Uji aktivitas antioksidan dengan metode DPPH ekstrak bromelain buah nanas (Ananas comosus (L.) Merr.). Skripsi Tidak Diterbitkan. Yogyakarta: Universitas Sanata Dharma.

Saifudin, A. (2014). Senyawa alam metabolit sekunder. Yogyakarta: Deepublish.

Sayuti, K., \& Yenrina, R. (2015). Antioksidan alami dan sintetik. Padang: Andalas University Press. 
Svehla, V. (1990). Buku teks analisis anorganik kualitatif makro dan semimikro. Jakarta: PT. Kalman Media Pustaka.

Taroreh, M., Raharjo, S., Hastuti, P., \& Murdiati, A. (2015). Ekstraksi daun gedi (abelmoschus manihot L) secara sekuensial dan aktivitas antioksidannya. Agritech, 35(3), 280-287.

Tiwari, P., Kumar, B., Kaur, M., Kaur, G., \& Kaur, H. (2011). Phytochemical screening and extractions. Journal Internationale Pharmaceutical Sciencia, 1(1), 98-106.

Utami, R. R., Supriyanto, S., Rahardjo, S., \& Armunanto, R. (2017). Aktivitas antioksidan kulit biji kakao dari hasil penyangraian biji kakao kering pada derajat ringan, sedang dan berat. Agritech, 37(1), 88-94.
Voight, R. (1995). Buku pelajaran teknologi farmasi. Yogyakarta: Universitas Gajah Mada Press.

Wagner, H., Bladt, S., \& Zgainski, E. M. (1984). Plant drug analysis a thin layer chromatography atlas. New York: Springer-Verlag.

Windono. (2001). Uji peredaman radikal bebas terhadap 1,1-diphenyl-2-picrylhydrazyl (DPPH) dari ekstrak kulit buah dan biji anggur (vitis vinivera L.) Probolinggo biru dan Bali. Artocarpus, 1(1), 34-43.

Yumas, M. (2017). Pemanfaatan limbah kulit ari biji kakao (Theobroma cacao L.) sebagai sumber antibakteri streptococcus mutans. Jurnal Industri Hasil Perkebunan, 12(2), 7-20. 